\title{
Study on the Employment-oriented College English Teaching Reform
}

\author{
Defang Ouyang ${ }^{1, a}$ \\ ${ }^{1}$ School of National Education, Nanchang Institute of science \& Technology, Nanchang 330108, \\ China; \\ azhouxiazju@163.com
}

Keywords: Employment-oriented, College English, Teaching Reform.

\begin{abstract}
In Recent years, with the college expansion, the number of college graduate in China has rapid increasing trend. Many graduate students have all faced growing pressure of employment. So it is imperative to develop the teaching reform of the employment-oriented college English. Based on the status of college English teaching, this paper has first analyzed the difference between college English teaching and the employment-oriented, and then has described the reform tendency of college English teaching from some aspects of the establishment of teaching goals, the improvement of professional qualities and diversified styles of evaluation.
\end{abstract}

\section{Introduction}

With the continued development of domestic economy, our society has higher demands on these students. Students should not only have professional quality, but also possess good inter-culture communication ability. However, many colleges have disregarded the training model of "employment-orientated and service-guided". The college education will disjoint with employment seriously. At present, most of colleges cannot relate basic knowledge of English to the practical application. So, it is very important to explore employment-oriented college English teaching. It can improve the comprehensive English applied ability of students, and plays a role in helping students to enhance own competitive ability.

\section{Present Situation of College English Teaching}

The Educational Idea of Some Teachers is Behind the Time. At present, the educational ideas of many college teachers aren't consistent with the college education development. Many teachers have still use traditional teaching model, which play a leading role in class. The situation of teaching practice is still as follows: the teachers are as the main subjects, and the face to face is the main method and the traditional method is still as its leading position. The traditional teaching model severely frustrates students' initiative. This teaching model cannot combine college English learning with social employment. In the traditional model, teachers have ignored the relation of knowledge with major, and training of students' application abilities. So, under the kind of traditional model, the graduate students will be short of On-the-job vocational skill and quality.

Lacking Real Language Learning Environment. In the term of curriculum and teaching environment, college English teaching lacks real language learning environment. This environment cannot make college students express their thinking with language. So the graduate students cannot meet the need of English application ability. In traditional teaching model, students cannot apply knowledge to their work. This will make students lack learning enthusiasm. The reason for this is because the curriculum is isolated. The college English teaching hasn't been fully recognized yet in whole college teaching system. They still see college English teaching as the basic public education, and haven't linked college English teaching with students' employment. For most students, they have learned English just for exams, and have ignored the nature of English learning. This notion leads the study motivation of students down the wrong path.

The Shortcomings of English Evaluation Mechanism. As for the English curriculum evaluation, it consists of a written test. There are some issues in the current evaluation method. The 
traditional evaluation method has focused on the gaining level of knowledge, and ignoring the English application ability of knowledge. Under the kind of traditional education model, the students only can read English words, but cannot speak English and apply English. The teaching model doesn't accord with the requirement of the current social development. Hence, the students will have a strong English reading ability of dealing with examination, but have a poor ability of dealing with communication with others.

\section{Difference Analysis of College English Teaching and Employment Orientation.}

The Factor of Students. From the perspective of employment, many firms or business not only require acquiring the relevant certificate of English exam, but also require the graduate students' skill to apply English dialogue expertly. It says surveys of the English-learning motivation indicate that the aim of learning English is meet the need of the college. In addition, for some students, the aim of learning English is to acquire a financial aid award. In that case, there is a gap between the graduated students and the requirement of enterprises, this gap will bring graduates employment pressures and seriously obstruct the cultivating of the innovative spirit and practical ability of the students.

The Factor of Teachers. Firstly, the English teachers have inadequate knowledge about teaching experience and language skills. Though teachers have a reasonable knowledge structure in the college, but high title teacher quantity are few. In addition, they are short of teaching experience and language skill. Secondly, the survey shows that some college English teachers have still followed the traditional instructional model in class. The multi-media teaching have been seldom used in English teaching. For this traditional method, it is hard to mobilize the enthusiasm and initiative of students to learn. It has become the main obstacles to implement college English teaching reform and improve students' speaking abilities of the English language. Thirdly, the teaching method has still adhered to the traditional teacher-centered and teaching materials instructional model. There is also practically no innovation. Most English teachers don't speak English in English lesson. Or in class, most students are willing to answer questions in Chinese, and they hope the teachers use Chinese. These traditional teaching models have seriously constraint to application ability of student development.

The Factor of Teaching Materials. The medium of instruction, teachers' choice of teaching materials for students to learn the English also has an important role in the English teaching. However, some English teachers have still used the old teaching materials. And they think that the current teaching materials can meet the need of English teaching. There are not a simple connection between teaching materials and enterprises requirement. From the present situation, few colleges have selected teaching materials of professional development as the English teaching materials. Most of English teaching materials don't keep pace with practice. Though the teachers and students have worked hard, the graduates have still hard to find job.

The Factor of Course Arrangement. In terms of curriculum, many colleges have kept using the old curriculum, they have gathered different majors of students to teach English. After the freshmen or sophomores take public English, specialized English courses will set to optional courses. Thus it can be seen that, most of college English curriculum are unreasonable. They pay less attention to specialized English teaching. It will impede improvement of English ability of students. During four years of college training, Students usually learns English for the first two years, and they have little contact with English teaching for the last two years. The model of curriculum will cause English ability decline. Because students haven't learned English for a long time, they have difficulty communicating with people by using English. The situation of teaching and teaching model of employment-orientation is vastly different.

The Factor of Teaching Environment. With the development of society and attention of college education, most colleges have expanded the scale unceasingly, and improved the teaching infrastructure, but these investments cannot meet the need of current English learning. In addition, in the course of English Learning, students have difficulty in finding a real pace of English learning. The English knowledge that they have learned from colleges is only learning-book, and 
cannot be taken part in any practical activities and workplace. The teaching environment has grown gaps between English communication ability and job. College English teaching has still taught the classroom as the center of teaching. Teachers have written the English words on the blackboards, and the students have written down what they say. Under the teaching environment, students cannot breakthrough the limitations of traditional English teaching models. The students don't know how to turn the English knowledge into practical application abilities. This way, they have fallen into rote learning habits. This is not in conformity with the requirements of English enterprises.

The Factor of Evaluation Mechanism. At present, the evaluation of college English teaching mainly depends on examination results. The evaluation has only focus on English knowledge, but has ignored actual application ability of English, learning interest, learning attitudes and learning method. The evaluation method has paid too much value on evaluation method while ignored the learning processing. The evaluation method has lagged behind the quality education requirements, which the development of practical English application abilities. The evaluation of Employment-center not only requires students to master English basic knowledge, but also requires students to communicate expertly with people by using English. So from the students' employment attitude part, the present English evaluation cannot meet the need of enterprises.

\section{The Tendency of Employment-oriented College English Teaching Reform}

Setting up Employment Orientation as English Teaching Goal. In terms of college English teaching characteristics, to enhance practical English application abilities of students, the English teaching based on practicality should be implemented in English teaching. Secondly, teachers should focus on training of basic English training of students, and teaching students some basic learning methods. Teachers should give the equal importance to the training of English theory and practical ability. Thirdly, teachers should help students to train some comprehensive skills in English teaching, such as speaking, listening, reading, writing and translation, etc. It aims to build up English social skills of students.

Promoting the Teacher Specialized Quality. Currently, the English application teaching should require a group of double qualified teachers. They should have not only solid English theory knowledge, but also abundant working experience. English teachers have taught not only English basic knowledge, but also practical knowledge. Teachers management departments should map out teachers training plan, give teachers a chance to receive training, and help teachers to promote their teaching idea and specialty quality.

Constructing the Employment-oriented College English Curricula System. College English curricula should be employment-orientation, and focus on developing the basic training and practical operating ability of English, so as to develop the students' ability to acquire information, which will pave the way for students' sustained development. In addition, the setting of English teaching content should focus on practicability, and keep pace with society development, so as to give students an advantage in job markets.

Constructing the Employment-oriented College English Teaching Environment. Most students cannot understand the words spoken to them in current educational environment. In addition, some students can't implement basic communication with foreigners. In order to run away from the difficulty and enhance job-hunting capability of college students, colleges should increase investment in English teaching facilities, construct modern teaching platform, and emulate real teaching platform and workplace. Firstly, colleges should provide the teaching environment based on multi-medium. Colleges can use multi-medium to play video in class, so as to expose students to real communication situation and improve the real perception of English. Secondly, in order to create a sense of English communication, it is necessary to introduce foreign teachers into English teaching. In foreign teacher English classes, students can implement pure English learning. Finally, teachers should enhance the practical training. After students had learned a certain textbook knowledge, colleges should offer more training course if possible. For example, colleges should create a better cooperation atmosphere between education and enterprise, so as to provide enterprise opportunities 
for college students, and guide students into enterprises environment. Under the teaching environment, students can experience the real application of English in the enterprise, and connect classroom knowledge with enterprise application. It will help students to develop students' capability to apply knowledge in different fields.

Implementing Diversified Examination Rule of Ability Examination. For examination management of English teaching, college English teaching reform has not only focused on examination score, but also has paid attention to English practical operation ability of students. First, college should change the traditional evaluation method, and adopt a new evaluation method of Employment-oriented and based on competency. For example, teachers can adopt evaluation method of " $2+1$ ". It is to say, companies and colleges should together take part in English evaluation of students. Enterprises should divided English application competence into multiple parts, and established relevant evaluation index system. Secondly, colleges should be focus on the evaluation of students own quality based on employment-orientation and competency evaluation. All social progress needs college graduates of strong English application abilities and high-quality in the long run.

\section{Summary}

English is the gateway to the world, and also a powerful tool for reaching other human beings. Though college English teaching of china has made certain progress, but it is equally undeniable that there are some shorts. To make great progress, the college and universities English teaching need shift ideological conception, establish clearly teaching goal based on employment-orientation, implement improvement of teaching model in time, so as to ensure the improvement of teaching activities and teaching effect. In the course of English applied talent development, we should quickly grasp the demand of the market, train comprehensive skills of students, so as to make students have great market competitive strength. In a word, the English reform in education of colleges and universities are imperative. Its achievement strengthens the quality-oriented education of English, and stress that English uses the cultivation of ability.

\section{References}

[1] Z.N.HU. Pratice and Design Principles of the College English Curriculum. Journal of Anhui University of Technology, 2(2005): 10-12.

[2] Y.LI, J.R.WANG. Construction of the College English Curriculum based on "Order Training” Mode , China Adult Education , 7(2008): 21-22.

[3] Y.C.YANG. Exploration on the Employment-oriented College English Teaching Reform. China Adult Education, 3(2013): 180-182.

[4] Y.Y.ZHANG. Exploration on the Employment-oriented College English Teaching Reform. English Campus, 5(2015): 50.

[5] Y.F.LI. Study on the College English Teaching Reform. ASIA-Pacific Education based on Employment, 15(2015):74.

[6] L. J. BIAN. Exploration on the Employment-oriented College English Teaching Model. Journal of Henan Institute of Finance and Tax College , 4(2015): 79-80. 